\title{
ИТОГИ СЕЛЕКЦИИ ОЗИМОЙ РЖИ В МОЛДОВЕ
}

\author{
Горе А.И, Лятамборг С.И., Ротарь С.Г. \\ Институт Генетики, Физиологии и Защчтты Растений, г. Кишинёв, Молдова \\ e-mail: andreigore57@gmail.com
}

\begin{abstract}
We have created the first rye zoned in 2008 year in Republic of Moldova from 2008 year Zambreni 70 by crossing (Haricovscaia $55 \mathrm{x}$ Tchiulpan). The productivity of this variety in average for 3 years was $-38.3 \mathrm{q} / \mathrm{ha}$ and Tchiulpan variety $-30.3 \mathrm{q} / \mathrm{ha}$. In average for three years (20122014) the variety of winter rye Tetram 34 obtained by mutation breeding from variety Belta had got the productivity $-34.0 \mathrm{q} / \mathrm{ha}$, what is better than Zambreni $70-32.8 \mathrm{q} / \mathrm{h}$ and Belta $-30.9 \mathrm{q} / \mathrm{h}$. The best nutation forms of winter rye sown in check-field produced grains in limits of 33-46 q/ha what is much more than check variety Inspector $-32 \mathrm{q} / \mathrm{ha}$.
\end{abstract}

Keywords: crossing, mutagenic factors, productivity, winter rye. 


\section{Введение}

Рожь - вторая хлебная культура в Молдове после пшеницы, а также используется как зернофуражная, для кормления животных. Во многих странах мира она не уступает по продуктивности озимой пшенице [4]. У нас в стране из зерновых по посевным площадям и валовому сбору, первая кукуруза, потом идет пшеница и ячмень. В настоящее время в Молдове озимая рожь сеется на небольших площадях и данные о ее возделывании не отражены в статистическом ежегоднике нашей страны [3]. Спрос на семена ржи выше чем предложение. Она культивируется на больших площадях в странах главного ржаного пояса, который простирается от северной Германии через Польшу, страны Скандинавии, Балтии, Украину Белоруссию и до центральной и северной России. На долю трех стран России, Германии и Польши приходится примерно 60-80\% мирового производства зерна ржи $[1,2]$. Велика роль этой культуры и в севообороте - угнетает сорняки, разрыхляет почву, а как культура сидерат удобряет почву в условиях, когда нет органических удобрений, поэтому является хорошим предшественником для многих культур [4,5].

Первое письменное упоминание о возделывании ржи в Молдове встречаем в работе Д.К. Кантемира «Описание Молдавии», написанное им в 1716 году, где он говорит, что рожь дает урожай в хорошие годы в 30 раз больше чем было посеяно.

В 1975 году в Молдове был районирован первый сорт озимой ржи - Белта (белорусской селекции). Второй сорт районированный в Молдове в 2008 году, был создан в нашей лаборатории - Зымбрень 70, а в 2015 году был районирован третий сорт - Инспектор (австрийской селекции). Нами был создан еще один сорт, но он не районирован - ТетраМ -34. В настоящее время в Молдове озимая рожь занимает небольшие площади в пределах нескольких тысяч гектаров. В основном она возделывается в качестве зерновой и зеленой кормовой культуры. Хлеб ржи по питательности превосходит хлеб пшеницы благодаря лизину, треонину и других аминокислот, а также пентоназам поэтому он незаменим при здоровом питании. ЮНЕСКО признало хлеб из этой культуры - мировым культурным наследием $[4,5,6]$.

Селекция ржи, как и других зерновых культур первой группы (пшеница, тритикале, ячмень и др.) направлена на создание новых форм и сортов интенсивного и полуинтенсивного типа, которые позволяют максимально использовать органические и минеральные удобрения с целью увеличения продуктивности зерна.

Целью наших исследований, исходя из выше сказанного, было создание нового исходного материала путем гибридизации и физического экспериментального мутагенеза, оценка и отбор новых устойчивых форм к полеганию, условиям зимы, жаре, засухе, осыпанию и болезням и с высокой продуктивностью.

\section{Материал и методы}

Для создания сорта Зымбрень 70 мы использовали межсортовые реципрокные скрещивания двух сортов озимой ржи: Харьковская 55 и Чулпан. Первый сорт высокорослый (130-140 см), среднеспелый с высокой зимостойкостью и кустистостью имеет крупный колос и крупное зерно. Сорт Чулпан - низкорослый $(85-90$ см) с относительно хорошей зимостойкостью и средней кустистостью.

В качестве исходного материала для создания сорта ТетраМ-34 был взят сорт озимой тетраплоидной ржи Белта. Было произведено облучение семян в дозах 100, 200, 300,400 и 500 грей. Облученные семена и контроль были посеяны в поле. А второй раз облучали сорт ТетраМ-34 гамма-радиацией в дозах 75, 100, 125 и 150 грей. В 
онтогенезе проводили фенологические наблюдения. Данные сравнивали с контрольным сортом Белта и ТетраМ-34.

\section{Результаты и обсуждения}

У гибридов $\mathrm{F}_{1}$ (Харьковская 55 х Чулпан) по длине соломины было промежуточное наследование по сравнению с родительскими формами. После созревания гибридов $\mathrm{F}_{1}$ все

типично гибридные растения были убраны вместе с корнями для биометрического анализа. Для дальнейшей работы были взяты растения с высотой $80-100$ см, с кустистостью 7-8 (хорошо развитых стеблей с колосьями) имеющие большое количество колосков (38-40) с $2.1-2.5$ зерен и больше, в каждом колоске средней части колоса. Во втором поколении было расщепление по высоте соломины в пределах 80 130 см. Для создания нового сорта ржи мы взяли растения с высотой $80-100$ см с хорошей кустистостью, зимостойкостью и адаптивностью к абиотическим и биотическим факторам среды. В среднем за 4 года (2002 - 2005) сорт Зымбрень давал урожай -38.3 ц/га, что на 8 ц/га выше чем у стандарта Чулпан. Лучшие линии озимой ржи, которые не колосились при весеннем посеве характеризовались высокой зимостойкостью и засухоустойчивостью были использованы для создания двух короткостебельных сортов озимой ржи, различающиеся по окраске вегетирующих растений: темно-зеленой (Зымбрень 70) и зеленой (Зымбрень 60). В среднем за 20022005 гг урожай указанных сортов составил 38.3 и 35.1 ц/га, что соответственно на 8.0 и 4.8 ц/га больше чем сорт Чулпан (табл.1).

Таблица 1. Продуктивность озимой ржи, ц/га

\begin{tabular}{|l|c|c|c|c|c|c|}
\hline \multirow{2}{*}{ Название } & \multicolumn{7}{|c|}{ Урожай зерна, ц.га } \\
\cline { 2 - 7 } & 2002 & 2003 & 2004 & 2005 & среднее & $\begin{array}{c}+- \text { к } \\
\text { станд. }\end{array}$ \\
\hline $\begin{array}{l}\text { Зымбрень 70 (70 линий } \\
\text { темно-зеленой окраски) }\end{array}$ & 52.0 & 22.0 & 42.0 & 37.4 & 38.3 & 8.0 \\
\hline $\begin{array}{l}\text { Зымбрень 60 (60 линий } \\
\text { зеленой окраски) }\end{array}$ & 51.0 & 17.0 & 41.2 & 31.3 & 35.1 & 4.8 \\
\hline Чулпан, стандарт & 42.0 & 14.0 & 35.0 & 30.3 & 30.3 & - \\
\hline
\end{tabular}

Осенью 2003 года сорт Зымбрень 70 был передан в Госкомиссию по сортоиспытанию сельскохозяйственных культур для испытания на госортоучастках страны. В 2004 и 2005 гг он показал хорошие результаты по продуктивности и устойчивости к биотическим и абиотическим факторам. В 2008 году сорт Зымбрень 70 был районирован во всех зонах Молдовы, на зерно и корм животных.

В M1 контроль и облученные семена сорта Белта были посеяны во второй декаде октября. Всхожесть семян при дозе 100 грей составила 63\%, 200 грей - 7 растений, а в контроле - 92\%. В вариантах 300, 400 и 500 грей семена не взошли из-за очень высокой дозы. У облученных растений увеличилось кущение, длина колоса, число колосков и зерен в колосе. Из общей массы зерна (100 грей) выделено 132 зерна зелено-белесого цвета, масса 1000 семян составила 55-56 гр. У диплоидной ржи масса 1000 семян составляет 32-32 гр., а у тетраплоидной - 42-43 гр.

В M2 (2010 год) из посеянных 617 зерен выделено более 220 колосьев имеющие от 3 до 18 колосков с тремя зернами в колоске. В 2012 году была выделена константная засухоустойчивая форма ржи с тремя и четырьмя зернами в средней части колоса, 
которая была посеяна в контрольном и конкурсном питомниках. Эта форма ржи была более урожайна чем контрольный сорт Белта, в среднем за 3 года на 3.1 ц/га. Эти данные о новом сорте ржи ТетраМ-34 в таблице 2.

Таблица 2. Характеристика и урожайность сортов ржи

\begin{tabular}{|l|c|l|l|l|l|}
\hline Вид ржи & $\begin{array}{l}\text { Число } \\
\text { хромосом }\end{array}$ & Сорта & $\begin{array}{l}\text { Масса } \\
1000 \\
\text { семян, } \\
\text { гр }\end{array}$ & $\begin{array}{l}\text { Фертильность } \\
\text { колоса, \% }\end{array}$ & $\begin{array}{l}\text { Ср.урожай } \\
2012- \\
2014 \Gamma \Gamma\end{array}$ \\
\hline Диплоидный & 14 & $\begin{array}{l}\text { Зымбрень 70 } \\
\text { (ст.1) }\end{array}$ & $31-32$ & $98-99$ & 32.8 \\
\hline Тетраплоидный & 28 & Белта (ст.2) & $\begin{array}{c}41.5- \\
42.0\end{array}$ & $96-99$ & 30.9 \\
\hline Тетраплоидный & 28 & ТетраМ 34 & $\begin{array}{c}42.0- \\
42.5\end{array}$ & $97-99$ & 34.0 \\
\hline
\end{tabular}

Осенью 2014 года облучили семена сорта ТетраМ-34 с целью получения нового исходного материала. Семена контрольного варианта (Т 34) и экспериментальных вариантов с дозой в 75, 100, 125 и 150 грей были посеяны в начале октября. Всхожесть семян в облученных вариантах была ниже (в пределах 60-79\%), а в контроле - 95\%. В М1 увеличилось в облученных вариантах кущение, длина колоса, число колосков и зерен в колосе, а длина растений наоборот уменьшилась. С М1 делали индивидуальный отбор растений с высотой меньше 120 см и с продуктивными колосьями имеющие больше колосков и зерен в колосе и по массе зерна с колоса. Отбирали на первых порах глазомерно колосья с 3-4 зернами. Самые лучшие семьи посеяли в селекционном питомнике. Как стандарт взяли сорт озимой ржи универсального типа (дающий хороший урожай в экстенсивных и интенсивных условиях возделывания) Инспектор.

Рожь в условиях 2019-2020 годов, когда была засуха в условиях осени, зимы и весны (хорошие дожди были только в мае и июне) была самая урожайная по сравнению с другими зерновыми культурами (озимая мягкая, твердая пшеница и тритикале).

Таблица 3. Урожай ржи в селекционном питомнике, 2020 год

\begin{tabular}{|l|c|c|c|}
\hline Название форм ржи & $\begin{array}{l}\text { Устойчивость к } \\
\text { полеганию }\end{array}$ & $\begin{array}{l}\text { Урожай, гр/0,6 } \\
\mathrm{m}^{2}\end{array}$ & $\begin{array}{l}\text { \%, по отношению } \\
\text { к стандарту }\end{array}$ \\
\hline Инспектор (станд) & 9 & 160 & - \\
\hline Зымбрень 70 & 9 & 150 & 93.7 \\
\hline ТетраМ-34 & 8 & 180 & 112.5 \\
\hline Сел. Т-34 & 9 & 200 & 125 \\
\hline Сел. Т-34 & 9 & 210 & 131.2 \\
\hline Т 150 & 9 & 220 & 137.5 \\
\hline T 75 & 9 & 250 & 156.2 \\
\hline
\end{tabular}

В селекционном питомнике были мутантные семьи, которые давали урожай 250-280 гр. с 0,6 м² по сравнению с контролем (сорт Инспектор) - 160 гр., у пшеницы (сорт Куяльник) - 100 гр. В контрольном питомнике были посеяны 5 мутантных форм озимой ржи, а как контроль сорт Инспектор. 
Таблица 4. Урожай ржи в демонстрационном питомнике, 2020 год

\begin{tabular}{|l|c|c|c|}
\hline Название форм ржи & $\begin{array}{l}\text { Устойчивость к } \\
\text { полеганию }\end{array}$ & $\begin{array}{l}\text { Устойчивость к } \\
\text { осыпанию }\end{array}$ & Урожай, ц/га \\
\hline Инспектор (станд) & 9 & 9 & 33.1 \\
\hline $\begin{array}{l}\text { Куяльник (станд) } \\
\text { пшеница }\end{array}$ & 9 & 9 & 21.7 \\
\hline Зымбрень 70 & 9 & 9 & 25.5 \\
\hline ТетраМ-34 & 8 & 9 & 34.5 \\
\hline
\end{tabular}

Все формы были устойчивы к полеганию и осыпанию и имели урожайность в пределах 30-46 ц/га по сравнению с сортом Инспектор - 32 ц/га и Куяльник (озимая пшеница) - 21.7 ц/га. В демонстрационном питомнике самый урожайный был сорт ТетраМ-34 - 34.5 ц/га по сравнению с Инспектором - 33.1 цга, Куяльник - 21.7 ц/га и Зымбрень 70 - 25.5 ц/га. Условия этого года нам указывают, что для продовольственной безопасности страны надо обязательно сеять и озимую рожь.

\section{Выводы}

1. За четыре года (2002-2005) сорт Зымбрень 70 давал урожай 38.3 ц/га, что на 8.0 ц/га больше чем у стандарта Чулпан. В 2008 году этот сорт был районирован в нашей стране.

2. В среднем за 3 года (2012-2014) сорт озимой ржи ТетраМ-34 имел урожай 34.0 цга, что лучше по сравнению с сортом Зымбрень $70-32.8$ ц/га и Белта -30.9 ц/га.

3. Перспективные мутантные формы озимой ржи посеянные в контрольном питомнике давали урожай в пределах 33-46 ц/га, что на много выше чем у сорта Инспектор - 32 ц/га.

1. https://ru.wikipedia.org

\section{Библиография}

2. https://en.wikipedia.org

3. Статистический ежегодник за 2018 год по Республике Молдова

4. Кобылянский В.Д. Рожь. Москва, Колос 1982, 71 стр

5. Растениеводство. Озимая рожь под ред.акад. П.П. Вавилов. М: Агропромиздат, 1986, стр. 54-67

6. E.M. Esimbaeva and others. New varieties of winter rye of intensive type // Bio Web conf. volume 17, 2020. International Scientific - Practical Conference "Agriculture and Food Security: Tehnology, Inovation, Markers, Human Resources» (FIES 2019), Article Number 00160. 